\title{
Comparison of eating attitudes among university students from the five Brazilian regions
}

\author{
Comparação das Atitudes Alimentares \\ entre universitárias das cinco regiões brasileiras
}

Marle dos Santos Alvarenga ${ }^{1}$

Fernanda Baeza Scagliusi ${ }^{2}$

Sonia Tucunduva Philippi ${ }^{1}$

${ }^{1}$ Departamento de Nutrição, Faculdade de Saúde Pública, Universidade de São Paulo (USP). Avenida Doutor Arnaldo 715, Cerqueira César. 01246-904 São Paulo SP.

marlealvarenga@gmail.com

${ }^{2}$ Campus Baixada Santista,

Depto de Ciências da Saúde,

Universidade Federal de São

Paulo
Abstract Eating attitudes can be defined as beliefs, thoughts, feelings, behavior and relationship with food. They can influence people's food choices and health status. The scope of this paper is to compare eating attitudes of university students from different regions of Brazil and investigate possible associations and correlations with nutritional status, age, individual income and parental education. 2489 female university students in the area of health answered the Eating Attitude Scale - evaluated by total score and 5 sub-scores. The eating attitudes were compared by means of an analysis of covariance. A logistic regression was conducted to evaluate which variables were associated to the scale score. The Northeast presented more restrictive and compensatory practices and the North and Northeast presented less positive feelings about food and worse ideas about normal eating. The score on the scale did not present strong correlation with any of the variables studied, but nutritional status and age were associated with the total score. The profile of university students was similar among regions with the worst response in the North and Northeast regions. It is believed that these data could help to elucidate dietary patterns and nutritional differences among groups.

Key words Eating attitudes, Female university students, Nutritional status
Resumo Atitudes alimentares são crenças, pensamentos, sentimentos, comportamentos e relacionamento com os alimentos e influenciam as escolhas alimentares e a saúde dos individuos. $\mathrm{Ob}$ jetivo: comparar atitudes alimentares de universitárias brasileiras das cinco regiões do país e avaliar associações e correlações com o estado nutricional, curso, idade, renda e escolaridade do chefe da família. Métodos: 2489 universitárias do sexo feminino de cursos da área da saúde responderam à Escala de Atitudes Alimentares - analisada em escore total e suas 5 subescalas. As respostas foram comparadas por região através da análise de covariância. Uma regressão logística foi realizada para avaliar quais variáveis estavam associadas à pontuação da escala. Resultados: a região Nordeste apresentou mais práticas restritivas e compensatórias e as regiões Norte e Nordeste menos sentimentos positivos em relação à alimentação e os piores conceitos sobre alimentação normal. Os escores não apresentaram forte correlação com as variáveis estudadas; mas o estado nutricional e a idade tiveram associação com a pontuação total. Conclusão: As atitudes alimentares de universitárias foram similares entre as regiões, com pior resposta na região Norte e Nordeste. Estes resultados podem ajudar a elucidar padrões dietéticos e diferenças nutricionais entre regiões do país.

Palavras-chave Atitudes alimentares, Universitárias, Estado nutricional 


\section{Introduction}

Eating is vital in life and a major determinant of health; it is thus important to study this subject from its different perspectives. Most studies in eating and nutrition have focused on physiological aspects, but if dissociated from their pertinent social environment is believed to produce only limited knowledge; for that reason, a cultural, psychological and social approach is necessary ${ }^{1}$. One possibility in this perspective is to study eating aspects besides the eating consumption, even in quantitative studies.

It is thus believed that people develop a relationship with food and the term "eating attitude" seems to better describe $i^{2,3}$. Considering the general definition of attitude from Oppenheim ${ }^{4}$ as "long-lasting clusters of feelings, beliefs, and cognitions in general, which may be positive or negative, toward a specific object that lead to actions that are coherent to the cognitions and feeling toward the specific object", Alvarenga et al. ${ }^{5}$ defined eating attitudes as one's beliefs, thoughts, feelings, behaviors and relationship with food and many studies in this area of knowledge also use the term attitude to describe thoughts, feelings and beliefs regarding eating ${ }^{3,6-9}$. Therefore, the term eating behavior does not encompass the correct idea of one relationship with food because it does not include the beliefs, thoughts and feelings towards food, while the term "eating attitudes" does.

Alvarenga et al..$^{5}$ developed and validated the Disordered Eating Attitude Scale (DEAS) based on this understanding of the construct. A suitably developed instrument allows performing food assessments in different groups and populations.

Rozin et al. ${ }^{3}$ claimed that different attitudes toward food may have an effect on overall health and contribute to differences in non-transmissible diseases. Different eating attitudes, especially regarding pleasure versus health concerns, can have an effect on overall health since pleasure apparently act as health promoters and worries can adversely affect health. It suggests that social and psychological components of eating, included in the concept of eating attitude, may be major health determinants ${ }^{3}$.

It is believed that food choices would be culturally determined but few studies have so far assessed the difference of attitudes among countries or different regions ${ }^{3,7}$. Comparing eating attitudes among different environments could provide input for studying the association between attitudes and the prevalence of obesity, eating disorders among others.
The issue of eating attitude has not been consistently discussed in Brazil. Nutritional Brazilian research generally has been investigating different food consumption and epidemiological profiles associated to the prevalence of nutritional diseas$\mathrm{es}^{10-12}$. The few studies concerning eating attitudes in Brazil analyzed clinical samples, especially those diagnosed with eating disorders ${ }^{13-15}$. Nevertheless, a significant increase of obesity rates have been seen in Brazil in all age groups and social strata ${ }^{16}$ and thus there is a need to better understand the attitudes toward eating and body weight presented by the general population, and not only those diagnosed with eating disorders. Besides that, Brazil is divided into regions which are characterized by diverse local population, type of settlement, weather conditions, and eating habits as well. From a nutritional perspective, little is known besides these regions have distinct prevalence of obesity and malnutrition $^{12}$, eating habits ${ }^{10}$ and food availability ${ }^{11}$. There is no study in Brazil investigating differences of eating attitudes among Brazilian regions. Thus, the study purpose was to compare eating attitudes evaluated by DEAS of female university students from different Brazilian regions and to investigate potential differences, associations and correlations with age, major, nutritional status, income and education of family head.

\section{Methods}

\section{Subjects}

In this assessment, it was opted to focus on eating attitudes of adult females since eating problems seem to be more significant among wom$\mathrm{en}^{1,3,17}$. Also, the DEAS was validated for the female young population ${ }^{5}$. A sample of universitary students was defined in order to evaluate young female subjects in a transversal study. The sample size was determined considering and calculations made by OpenEpi software (Dean AG, Sullivan KM \& Soe MM, Rollins School of Public Health - Emory University, Atlanta, GA, USA. Updated 2007). The calculations were made considering: a) $80 \%$ of power; b) $5 \%$ of significance; c) the total population of college women in Brazil, in $2005-2.488 .927^{18}$ and; d) the hypothesized percentual frequency of the outcome factor in this population $-8.3 \%^{19}$. Using these parameters it was verified that the necessary sample by region was 117 subjects.

Actually the truly outcome factor (eating attitudes) was never evaluated in Brazil with this 
focus. Then the outcome factor used was "eating attitudes" measure by the Eating Attitude Test (EAT-26), a well know and broadly used instrument in this field that was validated for Portuguese $^{20}$. The outcome found by Feio ${ }^{19}$ was chosen because it was found in a study with Brazilian university students in a random sample while others performed in Brazil with university students focus on specific majors, such as nutrition or medicine $e^{21,22}$.

In order to achieve the sample a partnership with public and private education institutions was sought. Formal invitations for research partnership were sent through e-mail to 130 higher education institutions that had undergraduate courses in nutrition and were listed in the National Nutrition Board in 2007. Due to geographical and other operational issues, study questionnaires were forwarded to coordinators of nutrition courses at the institutions that agreed to participate. A total of 37 (28.5\%) responded and signed the research partnership agreement required. Private and public institutions were invited for this partnership, nonetheless since a voluntary agreement was needed; a proportional distribution between the type of institution by region was not possible. From total, 8 (21.6\%) were public and the others private.

Subjects were selected mainly from nursing and psychology courses, which have predominantly female students, when these were not present they were selected from speech therapy, physical therapy, pharmacy and biomedicine as they were available in most institutions. For greater sample consistency, students attending the first and second year were invited to participate. Inclusion criteria were a) being females, b) aged over 18 and under 50 - to have a sample of young adult women c) to sign an informed consent agreeing to participate. Exclusion criteria were a) to be a dietitian or attending undergraduate studies in nutrition, b) being pregnant, c) to inform a health condition that could have an impact in eating attitudes (such as an eating disorder). Dietitians and/ or those attending undergraduate studies in nutrition were excluded because studies have showed that nutrition students have different eating behaviors $^{21,23}$. Physical education students were not invited to participate due to the fact that this area is related to nutrition and body issues.

In average 80 questionnaires were sent to each institution and partners invited students randomly. Overall, 2,925 instruments were sent during the second semester of 2007 and the first semester of 2008, and 2,547 filled instruments were re- ceived. The national response rate was $87.1 \%$, and by region it was: $94.1 \%$ for North (3 institutions), $95.7 \%$ for Northeast (5 institutions), $71.1 \%$ for Central West (5 institutions), 85.9\% for Southeast (12 institutions) and $89.0 \%$ for South (12 institutions). The response rate from Central West region was lower, but it was above than the necessary sample calculated by region.

Some questionnaires were excluded $(2.3 \%)$ because either information was missing or they were completed by a student who did not meet the inclusion criteria. Two students reported being pregnant and one reported being in treatment for anorexia nervosa and they were all excluded. The final sample included 2,489 university students.

Local coordinators received specific instructions about the DEAS administration. Following the inclusion and exclusion criteria, the questionnaire was then auto completed in the classroom and respondents were required to provide information such as age, self-reported body weight and height, individual income and education of family head. The nutritional status was classified according with Body Mass Index (BMI) categories ${ }^{24}$.

\section{Instrument}

The DEAS was developed based on the eating attitude construct as beliefs, thoughts, feelings, behaviors and relationship with food ${ }^{5}$. DEAS comprises 25 questions scored based on Likert scale, ranging from 37 to 190. An exploratory factor analysis was conducted and it was found that DEAS includes five subscales, named as: Subscale 1 - Relationship with food: evaluate attitudes related to the ways individuals deal with food in terms of food control, food refusal, guilt, anger, desire and shame; Subscale 2 - Concerns about eating and body weight gain: evaluate concerns about calories, intake control, obsessive thoughts about food and weight gain; Subscale 3 - Restrictive and compensatory practices: evaluate restriction of food and calories, and attitudes aiming to compensate large or uncontrolled food intake; Subscale 4 - Feelings toward eating: evaluate feelings concerning pleasure and food memories and how normal one feels to eat, and Subscale 5 - Idea of normal eating: evaluate rigid nutrition concepts and beliefs. The higher the score in the scale, the worse the attitude; thus, more dysfunctional (e.g. people with higher score at subscale 4 have less positive feelings about eating and don't consider the act of eating as normal as people that scored less). 
Cronbach's Alpha was 0.75 indicating that the scale has good internal consistency. The psychometric analysis concluded that the scale is valid and useful for evaluating eating attitudes in different population groups and eating disordered patients.

\section{Analysis}

Statistical analyses were conducted using SPSS 12.0 (Statistical Package for Social Science Inc., Chicago, Illinois USA). The significance level adopted was 0.05 . Categorical variables were described as the absolute and relative frequencies and quantitative variables as mean, median, standard deviation and range. Categorical variables were compared using the chi-square test or Fisher's exact test $(\mathrm{F})$.

The total score and the scores obtained by the five subscales of DEAS were compared among regions by means an analysis of variance using as fixed covariables: major, age, nutritional status (BMI categories), individual income and education of family head. The variables age, body weight, height, BMI, individual income and education of family head were also compared among regions. Levene's test for homogeneity of variances was performed. In the event of lack of homogeneity of variances the Brown-Forsythe (BF) test was performed for adjustment. Analysis of variance and post-hoc comparison tests (Bonferroni and Tukey test) were carried out to identify any differences found. In the event of adjustment using BF test, multiple comparisons (twoby-two) with the Dunnett's test were performed to identify differences among the groups.

Correlations coefficients between DEAS total score and its subscales were determined with the fixed covariables (major, age, BMI, individual income and education of family head). Pearson's coefficient was used for quantitative variables and Spearman's coefficient for qualitative ones.

A logistic regression was done to evaluate which variables were associated with the total scale score. The Stepwise forward model was used, that includes in the model just the independent variables with statistical significance $(\mathrm{p}<0.05)$, in this case, region, BMI and age.

All students signed a free informed consent form. The study was approved by the Research Ethics Committee of Public Health School - University of São Paulo.

\section{Results}

Of all, 240 subjects (9.6\%) were from the North region; 383 (15.4\%) from the Northeast; 199 (8\%) from the Central-West; $885(35.6 \%)$ from the Southeast, and 782 from the South $(31.42 \%)$. There were 1,462 nursing (58.7\%); 376 psychology (15.1\%), 305 pharmacy (12.3\%), 235 physical therapy $(9.4 \%), 44$ biomedicine (1.8\%), and 32 speech therapy students $(1.3 \%)$ - information about undergraduate course was missing for 35 (1.4\%).

Table 1 shows the distribution of age and BMI by region; statistically significant differences were found among regions, with higher mean values for age and BMI in the North and lower mean values in the Central West (24 years $/ 22.1 \mathrm{~kg} / \mathrm{m}^{2}$ and 20 years $/ 21.1 \mathrm{~kg} / \mathrm{m}^{2}$, respectively). The students were also divided into age groups: 685 $(27.5 \%)$ were between 18 and 19 years old; 1,054 (42.3\%) were between 20 and 24; 685 (27.5\%) were over 25 - and 65 (2.6\%) did not report age. A significant difference was also seen among regions when these categories of age were considered $(\mathrm{p}<0.001)$ with higher proportion of students over 25 years in the North and higher proportion of students with 18 to 19 years in the Central West.

When nutritional status was assessed using the BMI most subjects were at normal range with differences among regions (Table 1), but when BMI was classified according with all the categories presented by World Health Organization ${ }^{24}$ there was no statistical difference among regions (data not show). Only when underweight and obesity classes were grouped and normal range and pre obesity were considered, a significant difference was found among regions: a higher proportion of underweight was found in the Central West (14.7\%), normal range in the South (77.5\%), pre obesity in the North $(15.6 \%)$, and obesity (class 1,2 and 3) in the South (3.5\%).

Per capita monthly income was analyzed based on monthly minimum wages (MMWs), corresponding to $\mathrm{R} \$ 380.00$ as of 2007 . The majority of subjects reported individual monthly income lower than 2 MMWs and there was a statistical difference among regions, with higher proportion of 2-9.99 MMWs in the South and higher proportion of $\geq 10$ MMWs in the Northeast (Table 1). In regard to education of family head, Table 1 shows that most students reported college education (complete or not). There was a statistical dif- 
ference among regions with higher proportion of lower education in the Southeast and higher proportion of college education in the North.

The overall DEAS score by region and the scores in the five subscales are shown in Table 2. There was a statistical difference among regions in the overall DEAS score and in the Subscales 3, 4 and 5. The analysis of covariance showed that BMI had an effect on the overall DEAS score and this difference remained after adjusting for this variable, with North and Northeast regions presenting higher mean scores.

The analysis of covariance of subscales with a significant difference showed that BMI and age had an effect on Subscale 3 and the difference persisted after adjustment with higher mean scores in Northeast. As for Subscale 4, BMI had an effect on the model and the difference remained among regions with higher mean scores in North and Northeast. As for Subscale 5, the analysis showed that age, BMI and major had an effect on the final model. After adjustments and multiple comparisons, the mean score in the North was higher than in the other regions, followed by the Northeast.

As for the remaining subscales, BMI and age had an effect on Subscale 1 but this difference among regions disappeared after adjustment.

Table 1. Descriptive characteristics of sample at each Brazilian region. Female university students, Brazil, 2007-2008.

\begin{tabular}{|c|c|c|c|c|c|c|c|}
\hline Region & North & Northeast & Central-west & Southeast & South & $\begin{array}{l}\text { Total } \\
\text { nationwide }\end{array}$ & \\
\hline $\begin{array}{l}\text { AGE -years } \\
(\mathrm{n}=2424)^{\star}\end{array}$ & $26.1 \pm 7.1 ; 24^{\mathrm{a}}$ & $24.4 \pm 6.5 ; 23^{b}$ & $21.9 \pm 5.4 ; 20^{c}$ & $23.1 \pm 6.1 ; 21^{\mathrm{d}}$ & $23.0 \pm 5.3 ; 21^{\mathrm{e}}$ & $23.5 \pm 6.1 ; 21$ & $\mathrm{p}=0.001$ \\
\hline $\begin{array}{l}\text { BMI }-\mathrm{Kg} / \\
\mathrm{m}^{2}(\mathrm{n}=2357)^{\star}\end{array}$ & $22.7 \pm 3.5 ; 22.1^{\mathrm{f}}$ & $21.9 \pm 3.4 ; 21.4$ & $21.5 \pm 3.1 ; 21.1^{\mathrm{g}}$ & $22.2 \pm 3.7 ; 21.4$ & $21.9 \pm 3.3 ; 21.2$ & $22.0 \pm 3.5 ; 21.4$ & $\mathrm{p}=0.005$ \\
\hline \multicolumn{8}{|c|}{$\begin{array}{l}\text { Nutritional status categories using } b \\
(\%) \text { - Total answer } n=2357\end{array}$} \\
\hline $\begin{array}{l}\text { Underweight } \\
(\mathrm{BMI}<18.50)\end{array}$ & $12(5.7)$ & $49(13.5)$ & $28(14.7)$ & $79(9.4)$ & $61(8.1)$ & $229(9.7)$ & $\mathrm{p}=0.021$ \\
\hline $\begin{array}{l}\text { Normal range } \\
\text { (BMI 18.50- } \\
24.99)\end{array}$ & $160(75.8)$ & $255(70.0)$ & $139(72.8)$ & $622(73.9)$ & $582(77.5)$ & $1758(74.6)$ & \\
\hline $\begin{array}{l}\text { Pre obesity } \\
\text { (BMI } 25.00- \\
29.99)\end{array}$ & $33(15.6)$ & $51(14.0)$ & $20(10.5)$ & $114(13.55)$ & $82(10.9)$ & $300(12.7)$ & \\
\hline $\begin{array}{l}\text { Obesity class I, } \\
\text { II, III (BMI } \geq \\
30.00)\end{array}$ & $6(2.8)$ & $9(2.5)$ & $4(2.1)$ & $26(3.1)$ & $26(3.5)$ & $70(3.0)$ & \\
\hline \multicolumn{8}{|c|}{ Per capita monthly income in Monthly Minimum Wages- MMW - $n(\%)-$ Total answer $n=1958$} \\
\hline$<1.9$ MMW & $105(41.7)$ & $181(58.9)$ & $76(52.0)$ & $466(65.9)$ & $291(49.9)$ & $1119(57.1)$ & $\mathrm{p}=0.001$ \\
\hline $2.0-9.99 \mathrm{MMW}$ & $102(40.5)$ & $121(39.4)$ & $63(43.1)$ & $238(33.7)$ & $270(46.3)$ & $794(40.5)$ & \\
\hline$\geq 10 \mathrm{MMW}$ & $5(1.6)$ & $7(4.8)$ & $3(0.4)$ & $22(3.8)$ & $8(0.4)$ & $45(17.8)$ & \\
\hline \multicolumn{8}{|c|}{ Education of family head ${ }^{* *}-n(\%)-$ Total answer $n=2388$} \\
\hline $\begin{array}{l}\text { Illiterate or } \\
\text { elementary } \\
\text { education }\end{array}$ & $33(14.2)$ & $82(21.9)$ & $28(14.8)$ & $221(26.3)$ & $162(21.6)$ & $526(22.0)$ & $\mathrm{p}=0.001$ \\
\hline Middle education & $74(31.7)$ & $110(29.4)$ & $60(31.7)$ & $282(33.5)$ & $223(29.7)$ & $749(31.4)$ & \\
\hline $\begin{array}{l}\text { College } \\
\text { education }\end{array}$ & $126(54.1)$ & $182(48.7)$ & $101(53.4)$ & $338(40.2)$ & $366(48.7)$ & $1113(46.6)$ & \\
\hline
\end{tabular}

$\mathrm{a}=$ different from Northeast, Central-West, Southeast and South; $\mathrm{b}=$ different from North, Central-West, Southeast and South; $\mathrm{c}=$ different from Northeast and North; $\mathrm{d}=$ different from Northeast and North; $\mathrm{e}=$ different from Northeast and North; $\mathrm{f}=$ different from Central-West; $\mathrm{g}=\mathrm{different}$ from North. ${ }^{*}$ Data are described as mean \pm standard deviation; median. The total valid $n$ for each category in total country is indicated since not all students reported this information. ${ }^{\star *}$ For elementary education, middle school and college education including incomplete courses. 
Income and BMI had an effect on Subscale 2 but after controlling for these the difference among regions disappeared.

No strong correlation was found between the overall DEAS score and its related subscales and the covariables studied (all them under 30\%).

Logistic regression showed that North and Northeast regions students have, respectively, 2.20 and 2.46 the chance of a higher DEAS score than Central West; normal weight range students have 3.67 the chance of a higher DEAS score than underweight students and overweight students 10.6 the chance than underweight ones. It was also found that for each year increased of age, the chance for a higher DEAS total score decreases in $3 \%\left[(1-0,97)^{\star} 100\right]$.

\section{Discussion}

It was found that the profile of this group of Brazilian university students was similar with worse eating attitude in the North and Northeast regions. In all regions, the students were young, mostly (69.8\%) between 18 and 24 years of age, normal weight range $(74.6 \%)$, had a monthly income lower than 2 MMWs (57.1\%) and the family head had college education $(44.7 \%)$. It can be assumed that the differences found in mean ages, BMI, income and education among regions can be attributed to the sample size, which could potentially exacerbate small differences.

This study has the limitation of not use the truly outcome factor (eating attitudes) to determine the sample size. However, given the significant number of students participating and the fact that there are no other similar studies in Brazil, a profile of eating attitudes can be regarded as a starting point for further studies.

The nutritional profile of the sample was similar to that described nationwide for this stage of life. Most students are at normal range, and pre obesity and obesity were less prevalent than among female Brazilian adults, which are around $40 \%$ and $13.1 \%$, respectively ${ }^{16}$. Younger women are likely to have lower rates of excess weight than adults. The National Survey on Demographics

Table 2. Disordered Eating Attitude Scale (DEAS) overall score and subscales' scores by region of the female university students, Brazil, 2007-2008. Data described as mean \pm standard deviation (median; minimum - maximum).

\begin{tabular}{|c|c|c|c|c|c|c|c|}
\hline & $\begin{array}{l}\text { North } \\
(\mathrm{N})\end{array}$ & $\begin{array}{l}\text { Northeast } \\
\quad(\mathrm{NE})\end{array}$ & $\begin{array}{l}\text { Central-west } \\
(\mathrm{CW})\end{array}$ & $\begin{array}{l}\text { Southeast } \\
\text { (SE) }\end{array}$ & $\begin{array}{l}\text { South } \\
\text { (S) }\end{array}$ & Total & $p$ value \\
\hline 1) Relationship with food & $\begin{array}{c}21.0 \pm 8.6 \\
(18 ; 12-52) \\
n=240\end{array}$ & $\begin{array}{c}21.0 \pm 7.9 \\
(19 ; 12-56) \\
\mathrm{n}=383\end{array}$ & $\begin{array}{c}20.7 \pm 8.3 \\
(18 ; 12-52) \\
\mathrm{n}=199\end{array}$ & $\begin{array}{c}21.4 \pm 9.1 \\
(19 ; 12-60) \\
\mathrm{n}=885\end{array}$ & $\begin{array}{c}21.5 \pm 9.4 \\
(18 ; 12-60) \\
n=782\end{array}$ & $\begin{array}{c}21.3 \pm 8.9 \\
(18 ; 12-60) \\
n=2489\end{array}$ & 0.991 \\
\hline $\begin{array}{l}\text { 2) Concern with food and } \\
\text { weight gain }\end{array}$ & $\begin{array}{c}7.5 \pm 3.4 \\
(7 ; 4-20) \\
n=240\end{array}$ & $\begin{array}{c}7.1 \pm 3.3 \\
(6 ; 4-20) \\
n=383\end{array}$ & $\begin{array}{c}6.9 \pm 3.4 \\
(6 ; 4-20) \\
n=199\end{array}$ & $\begin{array}{c}7.4 \pm 3.7 \\
(6 ; 4-20) \\
n=885\end{array}$ & $\begin{array}{c}7.2 \pm 3.6 \\
(6 ; 4-20) \\
n=782\end{array}$ & $\begin{array}{c}7.3 \pm 3.6 \\
(6 ; 4-20) \\
n=2489\end{array}$ & 0.476 \\
\hline $\begin{array}{l}\text { 3) Restrictive \& } \\
\text { compensatory practices }\end{array}$ & $\begin{array}{c}6.8 \pm 3.8 \\
(6 ; 4-20) \\
n=240\end{array}$ & $\begin{array}{c}7.0 \pm 4.0 \\
(4 ; 4-20)^{\mathrm{a}} \\
\mathrm{n}=383\end{array}$ & $\begin{array}{c}6.6 \pm 3.6 \\
(4 ; 4-20)^{\mathrm{b}} \\
\mathrm{n}=199\end{array}$ & $\begin{array}{c}6.6 \pm 3.6 \\
(4 ; 4-20)^{c} \\
n=885\end{array}$ & $\begin{array}{c}6.7 \pm 3.9 \\
(4 ; 4-20)^{\mathrm{d}} \\
\mathrm{n}=782\end{array}$ & $\begin{array}{c}6.7 \pm 3.8 \\
(4 ; 4-20) \\
n=2489\end{array}$ & 0.049 \\
\hline 4) Feeling toward eating & $\begin{array}{c}4.2 \pm 2.1 \\
(3 ; 3-11)^{\mathrm{e}} \\
\mathrm{n}=240\end{array}$ & $\begin{array}{c}3.9 \pm 1.9 \\
(3 ; 3-15)^{\mathrm{f}} \\
\mathrm{n}=383\end{array}$ & $\begin{array}{c}3.6 \pm 1.7 \\
(3 ; 3-15) \\
n=199\end{array}$ & $\begin{array}{c}3.8 \pm 1.9 \\
(3 ; 3-15)^{\mathrm{g}} \\
\mathrm{n}=885\end{array}$ & $\begin{array}{c}3.7 \pm 1.8 \\
(3 ; 3-15)^{\mathrm{h}} \\
\mathrm{n}=782\end{array}$ & $\begin{array}{c}3.8 \pm 1.9 \\
(3 ; 3-15) \\
n=2489\end{array}$ & 0.032 \\
\hline 5) Idea of normal eating & $\begin{array}{c}27.8 \pm 7.4 \\
(26 ; 14-54)^{\mathrm{i}} \\
\mathrm{n}=228\end{array}$ & $\begin{array}{c}26.5 \pm 6.1 \\
(26 ; 14-52)^{j} \\
n=372\end{array}$ & $\begin{array}{c}24.2 \pm 5.7 \\
(24 ; 14-46)^{\mathrm{k}} \\
\mathrm{n}=192\end{array}$ & $\begin{array}{c}24.7 \pm 5.7 \\
(24 ; 14-50)^{1} \\
n=869\end{array}$ & $\begin{array}{c}25.4 \pm 6.5 \\
(24 ; 14-52)^{\mathrm{m}} \\
\mathrm{n}=773\end{array}$ & $\begin{array}{c}25.5 \pm 6.3 \\
(24 ; 14-54) \\
n=2434\end{array}$ & $<0.001$ \\
\hline DEAS total score & $\begin{array}{c}67.3 \pm 17.0 \\
(63 ; 41-135) \\
n=228^{n}\end{array}$ & $\begin{array}{c}65.7 \pm 15.3 \\
(63 ; 40-134)^{\circ} \\
n=372\end{array}$ & $\begin{array}{c}61.9 \pm 15.0 \\
(58 ; 37-115)^{\mathrm{p}} \\
\mathrm{n}=192\end{array}$ & $\begin{array}{c}64.0 \pm 16.1 \\
(60 ; 39-123) \\
n=869\end{array}$ & $\begin{array}{c}64.6 \pm 18.1 \\
(59 ; 37-167)^{\mathrm{q}} \\
\mathrm{n}=773\end{array}$ & $\begin{array}{c}64.6 \pm 16.7 \\
(60,5 ; 37-167) \\
n=2434^{\star}\end{array}$ & 0.013 \\
\hline
\end{tabular}

${ }^{\mathrm{a}}=$ different from CW, SE and $\mathrm{S} ;{ }^{\mathrm{b}}=$ different from NE; ${ }^{\mathrm{c}}=$ different from NE; ${ }^{\mathrm{d}}=\operatorname{different}$ from $\mathrm{NE} ;{ }^{\mathrm{e}}=$ different from $\mathrm{S}$ and $\mathrm{SE} ;{ }^{\mathrm{f}}=\operatorname{different}$ from $\mathrm{S}$ and $\mathrm{SE} ;{ }^{\mathrm{g}}=$ different from $\mathrm{NE}$ and $\mathrm{N} ;{ }^{\mathrm{h}}=$ different from $\mathrm{NE}$ and $\mathrm{N} ;{ }^{\mathrm{i}}=$ different from CW, SE and $\mathrm{S} ;{ }^{\mathrm{j}}=$ different from CW, SE and S; ${ }^{\mathrm{k}}=$ different from $\mathrm{NE}$, $\mathrm{N}$ and $S ;^{1}=$ different from NE, N and $S ;{ }^{\mathrm{m}}=$ different from NE, N, CW and SE; ${ }^{\mathrm{n}}=$ different from $\mathrm{CW}$ and $\mathrm{S} ;{ }^{\circ}=$ different from CW; ${ }^{\mathrm{p}}=$ different from $\mathrm{N}$ and $\mathrm{NE} ;{ }^{\mathrm{q}}=$ different from $\mathrm{N}$. ${ }^{*}$ The number of subjects is indicated by region and the total does not make the total number of subjects participating in the study since question 1 was left unanswered in some instances. It was opted to keep these subjects in the database so that DEAS subscales that not are related to question 1 (all but Subscale 5) could be analyzed. 
of Children and Women (PNDS) showed that $52.4 \%$ of women at the age 20 to 24 years are at normal range. The PNDS also evidenced that the prevalence of pre obesity declines as schooling increases ${ }^{25}$. It should be stressed, however, that weight and height were self-reported in the present study. A meta-analysis ${ }^{26}$ concluded that self-reported height and weight are good estimates of actual measures. In Brazil, studies ${ }^{27,28}$ found high consistency between self-reported and measured data and self-reported data are considered reliable when actual measures are not available for epidemiological studies.

As for monthly income, the majority reported a value lower than 2 MMWs. The Brazilian Household Survey (PNAD) reported a mean monthly income of R\$956.00 in 2007 (adjusted by the National Consumer Price Index), corresponding to $2.5 \mathrm{MMWs}^{29}$.

Elitization of the population studied is reflected by the education of family head, which resulted most had college education. PNAD data ${ }^{29}$ showed that only $8.6 \%$ of Brazilian adults over the age of 25 have fifteen or more years of study. The difference in the North and Northeast is even greater when comparing the rate of complete college education in adults found in PNAD (5.7\% and $4.9 \%$, respectively) and the proportion of college education of the family head found in the present study (54.1\% and $48.7 \%)$. Then, considering the education of family head as an indicative of social economic condition, seems that these North and Northeast students could be considered more elitized.

With respect to the eating attitudes, the analysis evidenced higher overall DEAS score in the North and Northeast, even after adjustments in the analysis of covariance. And for those subscales with statistically different scores after adjusting for covariables, the North region had the highest scores for Subscales 4 and 5. Differences in mean scores among regions were very small; and median overall score and subscale scores are quite similar in all regions. Besides that there is no homogeneity in the difference because the overall DEAS score and scores in Subscales 4 and 5 were not always statistically different among the same regions; and the score for Subscale 3 was higher in the Northeast and different from South, Southeast and Central West but not from North. Nevertheless, more inadequate eating attitudes were found in the North and Northeast. It can be thus assumed that those from the Northeast have more restrictive and compensatory practices (assessed by Subscale 3 ) and those from the North and Northeast have more negative feelings toward eating (Subscale 4). In addition, the most negative concept about normal eating (Subscale 5) was seen in the North, followed by the Northeast.

No strong correlations were found between DEAS scores (overall and subscales) and the variables studied; but besides region, the logistic regression showed that age and BMI were associated with the overall DEAS score, with younger and heavier students presenting more chance for worse eating attitude.

Mean and median DEAS scores suggest that university students in Brazil have very similar eating attitudes despite living in different regions. The differences found in the North and Northeast cannot be explained only by the variables studied. Eating habits, cultural background and lifestyle are known to differ in the five regions but since the proportion of university students is still small in Brazil, they are quite elitized and similar despite living in different areas.

Preliminary data of Vigitel research ${ }^{30}$ support in some way our result of worse attitudes in the North region. This research, conducted by phone using a probabilistic sample of 54,369 individuals in all Brazilian capitals, found that $13.6 \%$ of the individuals were dieting in order to lose weight and that Manaus was the capital with more individuals dieting $(17.1 \%)$.

The worse attitude in the North region was true for the subscales "feelings toward eating" (Subscale 4) and "idea of normal eating" (Subscale 5) that probably lead to a higher mean total score and consequently the most negative eating attitude (score in the overall DEAS). We could not find an explanation with the variables studied to these results of less feelings related with pleasure and also more rigid nutrition beliefs in students living in this region of the country. It is not possible to explain also the result of more restrictive and compensatory practices in the Northeast region. We are now exploring with this group of students the role of body image, media influence and eating behavior risk in the results of DEAS. Besides media influence and body image satisfaction, cultural background and ethnicity may be associated to the study findings and should be further investigated.

There is a general impression that the concerns and worries regarding diet, food, body and health are higher in more developed cities, as in the central south regions of Brazil. For example, the studies concerning risk behavior for eating disorders (ED) or clinical symptoms were mostly 
realized in the Southeast and South ${ }^{14,21,31-34}$, rarely in the Northeast ${ }^{22,35}$ and as long as we know none in the North region. Therefore the reality regarding these concerns in the North is in fact unknown. Besides the studies based on Pesquisa de Orçamentos Familiares - POF ${ }^{11,36,37}$ and Vigitel ${ }^{38}$, we also do not have knowledge of any study that compared food or nutrient intake among regions, especially in the same age group (as university students), thus we do not even know the possible differences in the North and Northeast of the country with regard food intake. There is not any facility center specialized in ED in the North. In conclusion, we do not know possible differences in the prevalence of ED in Brazilian regions and neither about the reality regarding food and body weight worries in the North and Northeast.

Anyway a potential globalization of information about food, diets, perception of the ideal body and concepts on nutrition should be considered as they seem to be widely disseminated in all regions as well in all age groups and socioeconomic strata. Another consideration involves the ethnic and cultural diversity of the Brazilian population but differences in race and ancestry were not explored in this study. Brazil was colonized by immigrants coming from different parts of the world; Europeans have settled mostly in the South and Southeast, Africans in the Northeast, while most of the native population remained in the North. However, due to similar age and socioeconomic condition, university students could likely have access to the same information and also to be subjected to the same socially accepted standards of eating and body as well. People in all Brazilian regions are widely exposed to the same movies, magazines, TV programs, fads and laws, especially in large urban areas where they have access to the same media. These facts could explain the result of any difference found for subscales 1 and 2 among regions.

To fully understand these differences, maybe a qualitative study will be necessary. Anyway, for the main objective of the present study (to compare eating attitudes of universitary students from 5 regions) a quantitative study was more appropriate - since we did not intend to analyze the influence of culture in the eating attitudes. Probably to understand how this relationship with food happens and developed and how the culture of each region interacts with these attitudes (to form a web of meanings), qualitative studies are needed, and it could be a future direction for research.

Rozin et al. ${ }^{17}$ investigated eating attitudes of 2,300 American college students from six differ- ent regions in the United States and "surprisingly" did not find major differences. They found no difference associated to either race or social condition, and the most important predictor was gender: women were more concerned with eating, weight and health. This pattern could probably be found in the present study if men were included.

DEAS questions are not the same used in the study of Rozin et al. ${ }^{17}$ but, for the sake of comparison, the DEAS question "I dream of a pill that could replace food" is close to the question "If I could eliminate eating by satisfying nutritional needs safely, cheaply and without hunger, with a pill, I would" ${ }^{17}$. They found that $34 \%$ of female American students agreed with this statement. In contrast, $14 \%$ of Brazilians said that they always, very often or often dream of having a pill to replace food. We believe that the wording "I dream of" has a stronger impact than the possibility of replacing food "if it would be safe, cheap and without hunger (...)". The dream of having a pill to replace meals has a stronger correlation with eating refusal.

Likewise, the DEAS question "Do you have pleasure eating?" is comparable to the question "Enjoying food is one of the most important pleasures in my life" from the American study ${ }^{17}$. In this study, $58 \%$ of women agreed with this statement while $95.7 \%$ of Brazilian women said they have pleasure eating. However, if the question were "one of the most important pleasures," the answers would likely be different.

It would be relevant to explore whether female (as well as male) adults in general - not only university students - would provide similar answers nationwide. Since a proportional distribution of private and public institutions was not possible for this sample - and a different socioeconomic profile could be found in these two publics - further studies should explore these groups. In addition to studying capitals and larger cities (where most universities are located), potential differences in eating attitudes between urban and rural populations and those living in capital and country cities should also be investigated. Further studies should be conducted to assess eating attitudes of both female and male, adolescents and adults from different locations and to compare their eating attitudes with those of people worldwide.

In conclusion, Brazilian university students have quite similar eating attitudes. Overall, the most inadequate eating attitudes, the most negative feelings toward eating and the most rigid 


\section{Collaborations}

MS Alvarenga was responsible for the research; FB Scagliusi was a research collaborator; ST Philippi was the supervisor of the pos doctorate program in which this research was included. All contributed for the analysis and discussion of the results and content composition. The authors reviewed the final versions and approved it.

\section{Acknowledgments}

The authors would like to thank The State of Sao Paulo Research Foundation - FAPESP for the grant that supported this research, and to thank the significant colaboration of nutrition courses coordinators in the data collection at institutions which participated in the research. of food practices and choices since it is not limited to the eating intake but otherwise to feelings, beliefs, thoughts and relationship with food. Nonetheless, there is much research to be done broadening the knowledge in which food relationship functions - especially about the development of the young female pattern of relations to food but also much to be learned about how and why eating attitudes and food choices are determined. Qualitative studies should be useful and must be performed in order to elucidate these issues.

\section{References}

1. Germov J, Williams L. The epidemic of dieting women: the need for a sociological approach to food and nutrition. Appetite 1996; 27(2):97-108.

2. Aikman SN, Crites Jr, SL. Structure of food attitudes: replication of Aikman, Crites, and Fabrigan 2006. Appetite 2007; 49(2):516-520.

3. Rozin P, Fischler C, Imada S, Sarubin A, Wrzesniewski A. Attitudes to food and the role of food in life in the USA, Japan, Flemish Belgium and France: possible implications for the diet-health debate. Appetite 1999; 33(2):163-180.

4. Oppenheim AN. Questionnaire design and attitude measurement. New York: Basic Books; 1966.

5. Alvarenga MS, Scagliusi FB, Philippi ST. Development and Validity of the Disordered Eating Attitude Scale (DEAS). Percept Mot Skills 2010; 110(2):379395.

6. Lamote S, Hermans D, Baeyens F, Eelen P. An exploration affective priming as an indirect measure of food attitudes. Appetite 2004; 42(3):279-286.

7. Roininen K, Tuorila H, Zandstra EH, de Graaf C, Vehkalahti K, Stubenitsky K, Mela DJ. Differences in health and taste attitudes and reported behaviour among Finnish, Dutch and British consumers: a cross-national validation of the Health and Taste Attitude Scales (HTAS). Appetite 2001; 37(1):33-45.

8. Sun YC. Health concern, food choice motives, and attitudes toward healthy eating: the mediation role of food choice motives. Appetite 2008; 51(1):42-49.

9. Verhulst F, Hermans D, Baeyens F, Spruyt A, Eelen P. Determinants and predictive validity of direct and indirect measures of recently acquired food attitudes. Appetite 2006; 46(2):137-143.

10. Fisberg M, Wehba J, Cozzolino SMF. Um, dois, feijão com arroz: a alimentação no Brasil de Norte a Sul. São Paulo: Atheneu; 2002.

11. Levy-Costa RB, Sichieri R, Pontes NS, Monteiro CA. Disponibilidade domiciliar de alimentos no Brasil: distribuição e evolução (1974-2003). Rev Saude Publica 2005; 39(4):530-540. 
12. Mondini L, Monteiro CA. Relevância epidemiológica da desnutrição e da obesidade em distintas classes sociais: métodos de estudo e aplicação à população brasileira. Rev Bras Epidemiol 1998; 1(1):28-39.

13. Alvarenga MS, Scagliusi FB, Philippi ST. Changing attitudes, beliefs and feelings towards food in bulimic patients. Arch Latinoam Nutr 2008; 58(3):274279.

14. Nunes MA, Barros FC, Olinto MTA, Camey S, Mari JDJ. Prevalence of abnormal eating behaviors and inappropriate methods for weight control in young women from Brazil: a population -based study. Eat Weight Disord 2003; 8(2):100-106.

15. Nunes MA, Olinto MTA, Barros FC, Camey S. Influência da percepção do peso e do índice de massa corporal nos comportamentos alimentares anormais. Rev Bras Psiquiatr 2001; 23(1):21-27.

16. Instituto Brasileiro de Geografia e Estatística (IBGE). Diretoria de Pesquisas. Coordenação de Índices de Preços. Pesquisa de orçamentos familiares 2002-2003. Análise da disponibilidade domiciliar de alimentos e do estado nutricional no Brasil. Rio de Janeiro: Instituto Brasileiro de Geografia e Estatística (IBGE); 2004. [accessed 2008 Jul 10]. [Document on the Internet]. Available from: http://www.ibge.gov.br/home/estatistica/ populacao/condicaodevida/pof/2002analise/pof2002 analise.pdf

17. Rozin P, Bauer R, Catanese D. Food and Life, Pleasure and Worry, among American college students: gender differences and regional similarities. J Pers Soc Psychol 2003; 85(1):132-141.

18. Brasil. Ministério da Educação (MEC). Senso da Educação Superior. Brasília: Instituto Nacional de Estudos e Pesquisas Educacionais Anísio Teixeira (INEP); 2005.

19. Feio LC. Prevalência de sintomas de anorexia nervosa e insatisfação com a imagem corporal em universitárias ingressantes na Universidade Federal de Santa Catarina [dissertação]. Santa Catarina (SC): Universidade Federal de Santa Catarina; 2007.

20. Bighetti F, Santos CB, Santos JE, Ribeiro RPP. Tradução e validação do Eating Attitudes Test em adolescentes do sexo feminino de Ribeirão Preto-SP. J Bras Psiquiatr 2004; 53(6):339-346.

21. Fiates GMR, Salles RK. Fatores de risco para o desenvolvimento de distúrbios alimentares: um estudo em universitárias. Rev Nutr 2001; 14 (Supl.):3-6.

22. Souza FGM, Martins MCR, Monteiro FCC, Neto GCM, Ribeiro IB. Anorexia e bulimia nervosa em alunas da Faculdade de Medicina da Universidade Federal do Ceará. Rev Psiquiatr Clin 2002; 24(4):172180.

23. Fredenberg JP, Berlung PT, Dieken HA. Incidence of eating disorders among selected female university students. J Am Diet Assoc 1996; 96(1):64-68.

24. World Health Organization (WHO). Global database on Body Mass Index. Geneva: World Health Organization (WHO); 2006. [accessed 2009 Mar 15]. [Document on the Internet]. Available from: http:// apps.who.int/bmi/index.jsp?introPage=intro_3.html

25. Lima ALL, Monteiro CA, Konno SC, Conde WL. Avaliação Antropométrica do estado nutricional de crianças e mulheres em idade fértil. In: Ministério da Saúde (MS). Pesquisa Nacional de Demografia e Saúde da Criança e da Mulher - 2006. Brasília (DF): Ministério da Saúde (MS); 2008.
26. Bowman R, De Lucia J. Accuracy of self-reported weight: A meta-analysis. Behav Ther 1992; 23(4):637655.

27. Fonseca MJM, Faerstein E, Chor D, Lopes CS. Validade de peso e estatura informados e índice de massa corporal: estudo pró-saúde. Rev Saude Publica 2004; 38(3):392-398.

28. Peixoto MRG, Benicio MHDJ, Veiga PCB. Validade do peso e da altura auto-referidos: o estudo de Goiânia. Rev Saude Publica 2006; 40(6):1065-1072.

29. Instituto Brasileiro de Geografia e Estatística (IBGE). Diretoria de Pesquisas. Pesquisa Nacional por Amostra de Domicílios - Síntese de Indicadores, 2007. Rio de Janeiro: Instituto Brasileiro de Geografia e Estatística (IBGE); 2008. [accessed 2008 Sep 18]. [Document on the Internet]. Available from: http://www.ibge.gov.br/ home/estatistica/populacao/trabalhoerendimento/ pnad2007/comentarios2007.pdf

30. Sardinha LMV, Moura L, Malta DC. Uso de medicamento e dieta para emagrecer na população adulta de todas as capitais Brasileiras e distrito federal VIGITEL 2006. In: XVIII Congresso Mundial de Epidemiologia e VII Congresso Nacional de Epidemiologia; 2008; Porto Alegre.

31. Bosi MLM, Luiz RR, Morgado CMC, Costa MLS, Carvalho RJ. Autopercepção da imagem corporal entre estudantes de nutrição no Rio de Janeiro. $J$ Bras Psiquiatr 2006; 55(1):34-40.

32. Dunker KLL, Philippi ST. Differences in the diet composition of Brazilian adolescent girls with positive or negative score in the Eating Attitudes Test. Eat Weight Disord 2005; 10(3):e70-e75.

33. Magalhães VC, Mendonça GAS. Transtornos alimentares em universitárias: estudos de confiabilidade da versão brasileira de questionários autopreenchíveis. Rev Bras Epidemiol 2005; 8(3):236-245.

34. Vilella JEM, Lamounier JA, Dellaretti Filho MA, Neto JRB, Horta GM. Transtornos alimentares em escolares. J Pediatr 2004; 80(1):49-54.

35. Siqueira KS, Appolinario JC, Sichieri R. Relationship between binge-eating episodes and self-perception of body weight in a nonclinical sample of five Brazilian cities. Rev Bras Psiquiatr 2005; 27(4): 290-294.

36. Mondini L, Monteiro CA. Mudanças no padrão de alimentação da população urbana brasileira (19621988). Rev Saude Publica 1994; 28(6):433-439.

37. Monteiro CA, Mondini L, Costa RBL. Mudanças na composição e adequação nutricional da dieta familiar nas áreas metropolitanas do Brasil (19881996). Rev Saude Publica 2000; 34(3):251-258.

38. Moura EC, Neto OLM, Malta DC, Moura L, Silva NN, Bernal R, Claro RM, Monteiro CA. Vigilância de fatores de risco para doenças crônicas por Inquérito telefônico nas capitais dos 26 estados brasileiros e no Distrito Federal (2006). Rev Bras Epidemiol 2008; 11(Supl. 1):20-37.

Artigo apresentado em 08/03/2010

Aprovado em 16/07/2010

Versão final apresentada em 09/08/2010 